\title{
PENGARUH KINERJA GURU BERSERTIFIKASI DAN BELUM BERSERTIFIKASI TERHADAP PRESTASI BELAJAR SISWA DI MIN SE-KABUPATEN SAMBAS
}

\author{
Purniadi Putra \\ Prodi PGMI Jurusan Tarbiyah Institut Agama Islam \\ Sultan Muhammad Syafiuddi Sambas \\ E-mail : usupurniadi@yahoo.com
}

Naskah diterima : 28 Desember 2016, direvisi : 29 Januari 2017, disetujui : 20 April 2017

\begin{abstract}
Abstrak
Sertifikasi pendidik dimaksudkan sebagai kontrol mutu hasil pendidikan, sehingga seseorang yang dinyatakan lulus dalam ujian sertifikasi pendidik diyakini mampu melaksanakan tugas mendidik, mengajar, melatih, membimbing, dan menilai hasil belajar peserta didik dan sangat berpengaruh dengan prestasi belajar siswa.

Penelitian ini bertujuan untuk mengetahui (1)Seberapa Besar Pengaruh Kinerja Guru Bersertifikasi terhadap Prestasi Belajar Siswa, (2) Pengaruh Kinerja Guru Belum Bersertifikasi terhadap Prestasi Belajar Siswa, (3) Pengaruh Kinerja Guru Bersertifikasi dan Belum Bersertifikasi Terhadap Prestasi Belajar Siswa.

Penelitian ini adalah penelitian survei dan expost facto (kausal komperatif). Dalam penelitian ini terdiri dari 2 variabel dan 2 kelompok yaitu variabel pertama kinerja guru dengan kelompok kinerja guru bersertifikasi dan kinerja guru belum bersertifikasi. Penelitian populasi dengan subjek penelitian yaitu Guru Bersertifikasi dan Belum Bersertifikasi di MIN Se-Kabupaten Sambas yang berjumlah 63 guru. Pengumpulan data dengan metode kuesioner. Uji validitas instrumen dengan teknik analisis product moment, sedangkan uji reliabilitas dengan koefisien alpha. Teknik analisis data menggunakan analisis regresi sederhana dan manova (menguji perbedaan mean). Sebelum analisis data terlebih dahulu diadakan pengujian persyaratan analisis uji normalitas.

Hasil penelitian menunjukkan bahwa: (1) Terdapat pengaruh positif dan signifikan Kinerja Guru pada Guru Bersertifikasi Terhadap Prestasi Belajar Siswa di MIN Se-Kabupaten Sambas yang ditunjukkan dengan nilai 0,393 atau 39,3\%. Hasil Kinerja Guru Bersertifikasi dinilai rendah yang dipengaruhi oleh variabel Prestasi Belajar Siswa di MIN Se-Kabupaten Sambas. (2)Terdapat pengaruh positif dan signifikan Kinerja Guru Belum Bersertifikasi Terhadap Prestasi Belajar Siswa di MIN Se-Kabupaten Sambas dengan nilai rendah yang ditunjukkan dengan nilai 0,257 atau 25,7\% dari variabel Prestasi Belajar Siswa. (3)terdapat pengaruh positif dan signifikan Kinerja Guru Pada Kelompok Guru Bersertifikasi dan Belum Bersertifikasi secara bersama-sama
\end{abstract}


terhadap Prestasi Belajar Siswa di MIN Se-Kabupaten Sambas juga cukup tinggi yakni masing-masing 0,926 dan 0,166.

Kata Kunci : Kinerja Guru Bersertifikasi dan Belum Bersertifikasi, Prestasi Belajar Siswa

Pengutipan: Putra, Purniadi. (2017). Pengarub Kinerja Guru Bersertifikasi dan Belum Bersertifikeasi terhadap Prestasi Belajar Siswa di MIN se-Kabupaten Sambas. JMIE: Journal of Madrasah Ibtidaiyah Education, 1(1), 2017, 14-27. sd.v1i1.22.

\section{Pendahuluan}

Pendidikan yang bermutu sangat tergantung pada kapasitas satuan-satuan pendidikan dalam mentranformasikan peserta didik untuk memperoleh nilai tambah, baik yang terkait dengan aspek olah pikir, rasa, hati, dan raganya. Dari sekian banyak komponen pendidikan, guru dan dosen merupakan faktor yang sangat penting dan strategis dalam usaha meningkatkan mutu pendidikan di setiap satuan pendidikan. Berapa pun besarnya investasi yang ditanamkan untuk memperbaiki mutu pendidikan, tanpa kehadiran guru dan dosen yang kompeten, profesional, bermartabat, dan sejahtera dapat dipastikan tidak akan tercapai (Undang-Undang R.I. Nomor. 14 Tahun 2005).

Keberhasilan dalam sebuah pendidikan yang berkualitas tidak terlepas dari faktor guru, siswa, sarana dan prasarana, lingkungan pendidikan dan kurikulum. Dari kelima faktor di atas apabila kita cermati bahwa faktor guru merupakan faktor yang sangat penting dan tidak dapat diganti oleh apapun, karena guru sebagai subyek pendidik dan sebagai penentu keberhasilan dalam pendidikan itu sendiri. Nana Sudjana menyebutkan bahwa prestasi siswa sangat dipengaruhi oleh guru dan guru merupakan pelaku utama dalam peningkatan prestasi belajar siswa (Sudjana, 2002: 42).

Prestasi belajar siswa sangat di pengaruhi oleh pelaku utama yaitu seorang guru. Guru sangat berperan aktif dalam penentu keberhasilan dalam pendidikan. Peran aktif guru mengelolah proses belajar mengajar di sekolah. Untuk meningkatkan mutu pendidikan maka diadakannya sertifikasi guru.

Sertifikasi profesi guru adalah proses untuk memberikan sertifikat kepada guru yang telah memenuhi standar kualifikasi dan standar kompetensi (Kunandar, 2007: 79). Upaya sertifikasi merupakan sarana atau instrument untuk mencapai suatu tujuan. Upaya sertifikasi ini hanyalah sebagai sarana untuk terciptanya kualitas seorang guru. Jika guru mengikuti sertifikasi, tujuan utama bukan untuk mendapatkan tunjangan profesi, melainkan untuk menunjukkan bahwa yang bersangkutan telah memiliki kompetensi atau layak disebut sebagai guru profesional (M. Zen, $2010: 15)$. 
Tuntutan keprofesionalan suatu pekerjaan pada dasarnya membutuhkan sejumlah persyaratan yang harus dimiliki oleh seseorang yang memangku jabatan tersebut. Persyaratan guru yang profesional antara lain : 1) menuntut adanya keterampilan yang berdasarkan konsep dan teori ilmu pengetahuan yang mendalam; 2) menekankan pada suatu keahlian dalam bidang tertentu sesuai dengan bidang profesinya; 3) menuntut adanya tingkat pendidikan keguruan yang memadai; 4) adanya kepekaan terhadap dampak kemasyarakatan dari pekerjaan yang dilaksanakannya; dan 5) memungkinkan perkembangan sejalan dengan dinamika kehidupan (Wahyudi, 2012 : 102).

Berdasarkan uraian di atas, kita ketahui bahwa untuk menjadi guru dengan predikat sebagai profesional tampaknya tidaklah mudah, tidak cukup hanya dinyatakan melalui selembar kertas yang diperoleh melaui proses sertifikasi. Namun guru dituntut untuk memiliki kemampuan menyelenggarakan proses pembelajaran dan penilaian yang menyenangkan dan sesuai dengan kriteria yang berlaku dengan tujuan agar dapat mendorong peningkatan dan tumbuhnya prestasi, motivasi, dan kreatifitas pada diri siswa.

Guru yang sudah bersertifikasi akan memberikan perubahan peningkatan prestasi belajar siswa. Prestasi belajar siswa ini dipengaruhi oleh beberapa faktor lingkungan, internal dan eksternal siswa, selain faktor utama peningkatan prestasi belajar siswa terletak bagaimana kualitas proses pembelajaran yang berlangsung. Oleh karena itu untuk meningkatkan prestasi belajar siswa, proses pembelajaran di kelas harus berlangsung dengan baik, berdaya guna dan berhasil guna. Proses pembelajaran akan berjalan dengan baik apabila didukung oleh guru yang mempunyai kemampuan profesional (tersertifikasi), karena guru merupakan faktor utama dalam tercapainya pelaksanaan pendidikan. Guru profesional atau yang telah bersertifikasi tentu akan mampu menumbuhkan semangat dan motivasi belajar siswa lebih baik (Muhaimin, 2003 : 175).

Guru yang sudah tersertifikasi diharapkan dapat menjadikan guru sebagai guru yang profesional. Sertifikasi guru merupakan sebuah terobosan dalam dunia pendidikan untuk meningkatkan kualitas dan profesionalitas seorang guru, sehingga ke depan semua guru harus memiliki sertifikat sebagai lisensi atau ijin mengajar. Dengan demikian, upaya pembentukan guru yang profesional di Indonesia segera menjadi kenyataan dan diharapkan tidak semua orang dapat menjadi guru dan tidak semua orang menjadikan profesi guru sebagai batu loncatan untuk memperoleh pekerjaan.

Perbedaan mencolok diantara guru bersertifikasi dan belum bersertifikasi hanya terletak pada 'predikat' yang melekat pada guru bersertifikat dan impian bakal mendapat tunjangan profesional. Sehingga yang muncul kemudian sejenis arogansi. Mereka yang telah bersertifikat merasa begitu yakin telah berhak mendapat tunjangan profesi, sekalipun secara kualitas tak jauh beda dengan guru yang tidak bersertifikat.

Parahnya, fenomena yang terjadi kemudian adalah, guru bersertifikat gencar 
menagih janji pemerintah untuk segera mencairkan tunjangan tersebut. Tentu saja ini sangat wajar, sebab selain mereka telah bersusah payah memenuhi portofolio, pemerintah juga telah berjanji memberikan reward. Lantas, yang tidak wajar adalah, tatkala mereka lupa bahwa reward tersebut sebenarnya hanya sejenis injeksi stimulasi atau perangsang agar guru selalu berupaya meningkatkan kualitas dan profesionalitasnya. Tanpa upaya peningkatan kualitas SDM yang timbul dari dalam diri guru, mustahil program sertifikasi guru melalui asesmen portofolio ini berhasil menciptakan dan meningkatkan pendidikan yang berkualitas. Portofolio telah memberikan andil besar pada terciptanya tertib administrasi di kalangan guru. Apa yang saya sebut terahir ini merupakan ekses positif, mengingat selama ini meskipun guru termasuk golongan intelektual, namun sekaligus golongan yang kerap mengabaikan administrasi (seperti mengisi agenda kelas, membuat program kerja sampai lupa mendokumentasikan hasil kerja). Jika demikian adanya, sekali lagi sertifikasi tidak menunjang peningkatan kualitas pendidikan (www.kabarindonesia. com).

Dalam penelitian ini masalah yang dapat ditemukan oleh penulis adalah sebagian kecil, seorang pendidik yang sudah lulus sertifikasi, masih belum maksimal dalam menjalankan tugasnya sebagai guru profesional, sehingga yang menjadi imbasnya adalah siswa sebagai anak didik tidak mendapatkan hasil pembelajaran yang maksimal.

Masalah yang terjadi di lapangan masih ditemukan adanya guru yang telah disertifikasi tidak bisa memperlihatkan RPP yang dibuat, dengan alasan ketinggalan di tempat sekolah lain tempat guru tersebut mengajar, dan bagi guru yang sudah membuat RPP masih terdapat ada guru yang belum melengkapi komponen tujuan pembelajaran dan penilaian (soal, skor dan kunci jawaban), hal itu diketahui pada saat peneliti mengadakan observasi terhadap RPP yang dibuat oleh guru yang telah disertifikasi (Chui Mi : 269).

Penelitian ini dilakukan di MIN Se-Kabupaten Sambas. Jumlah MIN di Kabupaten Sambas ada 3 MIN yaitu : MIN Sekuduk, jumlah gurunya 12 orang terdiri dari guru honor 3 dan 9 guru PNS sedangkan jumlah guru bersertifikasi ada 5 orang. MIN Sebebal jumlah gurunya 18 orang yang terdiri dari 7 guru honor dan 11 guru PNS jumlah guru bersertifikasi 1 orang. dan MIN Pemangkat jumlah gurunya ada 36 orang yang terdiri dari guru honor 13 orang dan PNS 23 orang sedangkan jumlah guru bersertifikasi 8 orang. Dengan demikian dapat dilihat pengaruh kinerja guru yang bersertifikasi dengan yang belum disertifikasi terhadap prestasi belajar siswa di MIN Se-Kabupaten Sambas. Dalam penelitian ini jumlah guru yang ada pada 3 MIN di Kabupaten Sambas yaitu ada 66 orang yang terdiri dari guru bersertifikasi ada 14 orang dan yang belum bersertifikasi ada 52 orang.

Berdasarkan latar belakang di atas, maka peneliti tertarik untuk melakukan penelitian secara umum dalam penelitian ingin mendeskripsikan kinerja yang dilakukan oleh guru yang bersertifikasi dan belum sertifikasi dalam meningkatkan 
prestasi belajar siswa di MIN Se-Kabupaten Sambas dan pembahasannya ingin mengetahui secara riil apakah ada pengaruh guru yang bersertifikasi dan belum bersertifikasi terhadap prestasi belajar siswa di MIN Se-Kabupaten Sambas. Maka bentuk judul proposal tesis "Pengaruh Kinerja Guru Bersertifikasi dan Belum Bersertifikasi Terhadap Prestasi Belajar Siswa Di MIN Se-Kabupaten Sambas".

\section{Pengertian guru}

Sosok guru adalah orang yang identik dengan pihak yang memiliki tugas dan tanggung jawab membentuk karakter generasi bangsa.Tugas dan tanggung jawab seorang guru tentunya memiliki dedikasi hidupnya untuk mendidik siswa dan orang-orang disekitarnya agar dapat menjadi tunas-tunas bangsa yang akan tumbuh dan menjadi pembangun bangsa sesuai dengan cita-cita proklamasi kemerdekaan dan amanat UUD 1945 (Rizali dkk, 2009 : 1).

\section{Peranan dan Tugas Guru}

Adapun secara terperinci tugas seorang guru berpusat pada :

a. Mendidik dengan titik berat memberikan arah dan motivasi pencapain tujuan baik jangka pendek maupun jangka panjang.

b. Memberikan fasilitas pencapaian tujuan melalui pengalaman belajar yang memadai.

c. Membantu aspek-aspek pribadi, seperti sikap, nilai-nilai, dan penyesuaian diri.

\section{Sertifikasi Guru}

Sertifikasi guru adalah proses pemberian sertifikat pendidik kepada para guru. Sertifikat ini diberikan kepada para guru yang telah memenuhi standar profesional. Sasaran terakhirnya yakni menciptakan guru yang profesional (M. Zen, 2010 : 13).

Sertifikasi profesi guru adalah proses untuk memberikan sertifikat kepada guru yang telah memenuhi standar kualifikasi dan standar kompetensi. Sertifikasi dilakukan oleh perguruan tinggi penyelenggara pengadaan tenaga kependidikan yang terakreditasi dan ditetapkan oleh pemerintah.

\section{Tujuan Sertifikasi Guru}

Dalam panduan dari Diknas disebutkan bahwa, tujuan sertifikasi guru adalah (M. Zen, $2010: 14)$ :

a. Menentukan kelayakan guru dan melaksanakan tugas sebagai agen pembelajaran dan mewujudkan tujuan pendidikan nasional

b. Meningkatkan proses dan mutu pendidikan yang akan di capai

c. Meningkatkan profesionalitas seorang guru

Tujuan dari sertifikasi guru merupakan tujuan pemerintah untuk meningkatkan 
mutu pendidikan. Dalam meningkatkan mutu pendidikan itu kualitas guru sangat menentukan untuk mewujudkan tujuan pendidikan nasional.

\section{Prinsip Sertifikasi Guru}

Prinsip-prinsip guru bersertifikasi sebagai berikut (M. Zen, 2010 : 14) :

a. Memiliki bakat minat, panggilan jiwa, dan idealism.

b. Memiliki komitmen untuk meningkatkan mutu pendidikan, keimanan, ketakwaan, dan akhlak mulia.

c. Memiliki kualifikasi akademik dan latar belakang pendidikan yang sesuai dengan bidang tugas.

d. Memiliki tanggung jawab atas pelaksanaan keprofesionalan.

Dari beberapa Prinsip sertifikasi di atas merupakan prinsip keprofesioanalisme seorang guru dalam menjalankan tugas dan tanggung jawabnya. Prinsip yang dimiliki oleh guru yang bersertifikasi itu harus profesional. Guru yang profesional merupakan faktor penentu proses pendidikan yang berkualitas.

\section{Ciri-Ciri Guru Tersertifikasi}

\section{a. Memiliki Kompetensi Dasar dalam pendidikan}

Kompetensi merupakan perilaku rasional untuk mencapai tujuan yang dipersyaratkan sesuai dengan kondisi yang telah ditentukan. Dengan kata lain bahwa kompetensi dapat dipahami sebagai kecakapan atau kemampuan.

Kualifikasai kompetensi minimal di atas harus dimiliki oleh guru dalam pencapaian guru profesional antara lain:

\section{Kompetensi Pedagogik}

Kompetensi pedagogik yaitu kemampuan seorang guru dalam mengelola pembelajaran yang meliputi pemahaman terhadap siswa, perancangan dan pelaksanaan pembelajaran, evaluasi pembelajaran, dan pengembangan siswa untuk mengaktualisasikan berbagai potensi yang dimilikinya (Wahyudi, 2012 : 115). Kompetensi ini dijabarkan menjadi sub kompetensi, yaitu:
a) Memahami karakteristik siswa dari aspek fisik, sosial, moral, kultur, emosional, dan intelektual
b) Memahami latar belakang keluarga dan masyarakat siswa, dan kebutuhan belajar dalam kontek kebhinekaan budaya
c) Memahami gaya belajar dan kesulitan belajar siswa
d) Memfasilitasi pengembangan potensi siswa
e) Menguasai teori dan prinsip belajar serta pembelajaran yang mendidik. 


\section{Kompetensi Profesional}

Guru yang profesional adalah mereka yang secara spesifik memiliki pekerjaan yang didasari oleh keahlian keguruan dengan pemahaman yang mendalam terhadap landasan kependidikan, dan atau secara akademis memiliki pengetahuan teori-teori kependidikan dan memiliki untuk dapat mengimplementasikan teori kependidikan tersebut (Rusman, 2011 : 70).

Kemampuan tersebut diwujudkan dalam bentuk kemampuan:

a) Menguasai substansi bidang dan metodologi keilmuannya

b) Menguasai struktur dan materi kurikulum bidang studi

c) Menguasai dan memanfatkan teknologi informasi dan komunikasi dalam pembelajaran

d) Mengorganisasikan materi kurikulum bidang studi

e) Meningkatkan kualitas pembelajaran melalui penelitian tindakan kelas (PP no. 19 Tahun 2005).

\section{Kompetensi Kepribadian}

Kompetensi kepribadian (personality) adalah kemampuan yang melekat dalam diri pendidik secara mantap, stabil, dewasa, arif, dan berwibawa menjadi teladan bagi peserta didik, dan berakhlak mulia (Fatah, 2008 : 76).

Kompetensi tersebut diekspresikan dalam bentuk kemampuan:

a) Menampilkan diri sebagai pribadi yang mantap, stabil, dewasa, arif, dan berwibawa.

b) Menampilkan diri sebagai pribadi yang berakhlak mulia dan sebagai teladan bagi siswa dan masyarakat,

c) Menunjukkan etos kerja, tanggung jawab yang tinggi serta bangga menjadi guru, dan rasa percaya diri

d) Menujung tinggi kode etik profesi guru

e) Mengevaluasi kinerja sendiri, dan

f) Mengembangkan diri secara berkelanjutan (Wahyudi, 2012:111-112).

\section{Kompetensi Sosial}

Kompetensi sosial, yaitu kompetensi pada bidang hubungan dan pelayanan, dapat berkomunikasi dengan orang lain, mampu menyelesaikan masalah, pengabdian pada masyarakat (Hujair, 2005 : 7-8).

Kompetensi tersebut ditunjukkan dalam bentuk kemampuan, sebagai berikut:

a) Berkomunikasi secara efektif dan empatik dengan siswa, orang tua siswa, sesama pendidik, tenaga kependidikan, dan Masyarakat 
b) Berkontribusi terhadap pengembangan pendidikan di sekolah dan masyarakat,

c) Berkontribusi terhadap pengembangan pendidikan di tingkat lokal, regional, nasional, dan global,

d) Memanfaatkan teknologi informasi dan komunikasi (ICT) untuk berkomunikasi dan mengembangkan diri.

\section{Kinerja Guru Tersertifikasi}

Dalam pengertian kinerja guru sebagai pengajar adalah prilaku atau respons yang memberikan hasil yang mengacu kepada apa yang mereka kerjakan ketika seorang guru dalam menghadapi tugasnya. Dalam kaitan dengan kinerja tenaga pengajar pada dasarnya lebih terfokus pada pekerjaan, demikian dalam hal efektivitas tenaga pengajar adalah sejauh mana kinerja tersebut dapat memberikan pengaruh kepada siswa (Yamin, $2010: 87$ ).

\section{Kinerja Guru Profesional}

Guru yang profesional adalah guru yang memiliki mutu dan kualitas layanan dan produknya, layanan guru harus memenuhi standarisasi layanan masyarakat, bangsa dan pengguna serta memaksimalkan kemampuan peserta didik berdasarkan kompetensi yang dimiliki masing-masing individu.

\section{Indikator Kinerja Guru}

Dalam menilai kualitas kinerja guru ditinjau dari beberapa indikator yang meliputi (Saondi, $2010: 21-23$ ):

a. Unjuk kerja atau kinerja dalam konteks profesi guru yaitu kegiatan yang meliputi perencanaan pembelajaran, pelaksanaan pembelajaran/KBM dan melakukan penilaian hasil belajar.

b. Penguasaan materi

c. Penguasaan profesional keguruan dan pendidikan.

d. Penguasaan cara-cara penyesuain diri.

e. Kepribadian untuk melaksanakan tugasnya dengan baik

\section{Penilaian Kinerja Guru}

Evaluasi hasil tugas adalah mengevaluasi hasil pelaksanaan kerja individu dengan beberapa kriteria (indikator) yang dapat di ukur. Evaluasi prilaku dapat dilakukan dengan cara membandingkan prilakunya dengan rekan kerja yang lain dan evaluasi ciri individu adalah mengamati karakteristik individu dalam berprilaku maupun bekerja. Evaluasi atau penilaian kinerja menjadi penting sebagai feed back sekaligus sebagai follow up bagi perbaikan kinerja selanjutnya (Saondi, 2010 : 23). 


\section{Pengertian Prestasi Belajar}

Dari beberapa pengertian di atas pengertian prestasi dapat dikemukan bahwa Prestasi belajar adalah hasil atau taraf kemampuan yang telah dicapai siswa setelah mengikuti proses belajar mengajar dalam waktu tertentu baik berupa perubahan tingkah laku, keterampilan dan pengetahuan dan kemudian akan diukur dan dinilai yang kemudian diwujudkan dalam angka atau pernyataan.

\section{Faktor-Faktor yang Mempengaruhi Prestasi Belajar}

\section{a. Faktor dari dalam diri siswa (internal)}

Sehubungan dengan faktor intern ini ada tingkat yang perlu dibahas yaitu faktor jasmani, faktor psikologi dan faktor kelelahan (Slameto, 2003 : 54). Faktor Jasmaniah (fisiologi) baik yang bersifat bawaan maupun yang diperoleh. Yang termasuk faktor ini adalah panca indera yang tidak berfungsi sebagaimana mestinya seperti mengalami sakit, cacat fisik/tubuh atau perkembangan yang tidak sempurna serta adanya kelelahan.

1. Faktor yang berasal dari luar diri (eksternal)

Faktor eksternal merupakan faktor yang mempengaruhi prestasi belajar siswa yang bersumber dari luar diri seseorang. Menurut Singgih D. Gunarsa ada beberapa hal yang mempengaruhi kualitas prestasi belajar siswa.

2. Faktor lingkungan Keluarga

Kondisi lingkungan keluarga sangat menentukan hasil belajar seseorang. Yaitu adanya hubungan yang harmonis dalam keluarga, tersedianya fasilitas belajar, keadaan ekonomi yang cukup, suasana yang mendukung dan perhatian orang tua terhadap perkembangan proses belajar anak.

3. Faktor Lingkungan Sekolah

Lingkungan Sosial Sekolah, seperti guru, administrasi, dan teman-teman sekelas dapat mempengaruhi semangat belajar siswa.

4. Lingkungan Sosial Masyarakat

Lingkungan siswa yang kumuh, banyak pegangguran dan anak terlantar juga dapat memengaruhi aktivitas belajar siswa, paling tidak siswa kesulitan ketika memerlukan teman belajar, diskusi, atau meminjam alat-alat belajar yang kebetulan belum dimilikinya (Baharudin \& Esa, 2012 : 26).

\section{Penilaian Terhadap Prestasi Siswa}

Hasil belajar psikomotorik tampak dalam bentuk skill dan aktivitas siswa. Menurut Nana Sudjana hasil belajar psikomotorik merupakan tahap kelanjutan dari belajar afektif, sehingga aktivitas yang muncul merupakan kelanjutan dari sikap (afektif) seperti segera memasuki kelas saat guru datang, mencatat bahan pelajaran, membaca buku referensi, latihan mengerjakan soal, mampu bergaul dan 
lain sebagainya (Sujana, 1995 : 31).

\section{Metode Penelitian}

Penelitian ini menggunakan pendekatan kuantitatif, karena data yang dihasilkan melibatkan perhitungan angka atau kuantitas, selain itu analisa data dalam penelitian ini menggunakan statistik (Azwar, 1999 : 5). Sedangkan jenis penelitian ini menggunakan pendekatan kuantitatif dengan teknik metode penelitian survei (Iqbal Hasan : 5) dan expost facto (kausal komperatif).

\section{Hasil Penelitian}

Adapun temuan penelitian yang didapatkan di lapangan tentang pengaruh kinerja guru bersertifikasi dan faktor-faktor yang mempengaruhinya di MIN SeKabupaten Sambas bahwa kinerja guru bersertifikasi terhadap prestasi belajar siswa dari hasil analisis menunjukkan adanya pengaruh kinerja guru yang bersertifikasi terhadap prestasi belajar siswa di MIN Se-Kabupaten Sambas dengan signifikansi $\mathrm{t}$ sebesar 0,016 < 0,05. Hasil ini didapat dari analisis pengaruh Kinerja Guru pada kelompok Guru Bersertifikasi terhadap Prestasi Belajar Siswa yaitu 0,393 persentasenya adalah 39,3\%. Kinerja guru bersertifikasi di MIN Se-Kabupaten Sambas dikatakan masih rendah disebabkan oleh beberapa faktor yaitu

a. Guru yang bersertifikasi itu rata-rata pada faktor usia yang sudah lanjut, sehingga proses dalam pembelajaran kurang efektif dalam memberikan pengajaran, guru di MIN Se-Kabupaten Sambas yang lulus sertifikasi hanya berdasarkan lamanya mengajar bukan dikarnakan oleh uji kompetensi.

b. Temuan penelitian di lapangan bahwa bahwa sebagian guru bersertifikasi kurang dalam pengembangan sikap selama dalam jabatan. Pengembangan sikap profesional keguruan dalam peningkatan kinerjanya dapat dilakukan dengan cara formal misalnya melalui kegiatan mengikuti penataran, lokakarya, seminar, atau kegiatan ilmiah lainnya, ataupun secara informal melalui media massa televisi, radio, koran, dan majalah maupun publikasi lainnya. mengikuti kegiatan pengembangan kurikulum.

c. Guru bersertifikasi di MIN Se-Kabupaten Sambas kebanyakan kurang terampil dalam menggunakan teknologi informatika.

d. Masalah yang terjadi di lapangan masih ditemukan adanya guru yang telah disertifikasi tidak bisa memperlihatkan RPP yang dibuat.

Adapun temuan penelitian yang didapatkan di lapangan tentang pengaruh kinerja guru belum bersertifikasi dari hasil analisis data terbukti bahwa ada pengaruh positif signifikan kinerja guru belum bersertifikasi terhadap prestasi belajar siswa MIN Se-Kabupaten Sambas (signifikansi $t=0,000<0,05$ ). Dari hasil nilai yang diperoleh dari koefisien korelasi yaitu 0,257 . Hal ini menunjukkan Indeks Determinasi, yaitu persentase yang mengembangkan pengaruh kinerja 
guru pada kelompok belum Bersertifikasi terhadap Prestasi Belajar Siswa yaitu $25,7 \%$ terhadap prestasi belajar siswa.

Hasil penelitian yang mempengaruhi kinerja guru belum bersertifikasi terhadap prestasi belajar siswa di MIN Se-Kabupaten Sambas terdiri dari beberapa faktor yaitu :

a. Temuan penelitian di lapangan bahwa kinerja guru belum bersertifikasi di MIN Se-Kabupaten Sambas terhadap prestasi belajar siswa yang salah satunya mempengaruhi kompetensi guru yaitu faktor latar belakang pendidikan dan pengalaman mengajar.

b. Temuan penelitian yang didapat di lapangan juga disebabkan oleh faktor motivasi kerja yang dilakukan oleh kinerja guru belum bersertifikasi temuan bahwa, pengaruh kinerja guru belum bersertifikasi dikatakan rendah. Hal ini membuktikan bahwa pengaruh kinerja guru belum bersertifikasi rendah dibandingkan temuan yang ada.

Rendahnya temuan ini dikarenakan oleh :

a. Penghasilan yang diperoleh guru belum mampu memenuhi kebutuhan hidup harian keluarga secara mencukupi, sehingga guru yang ada di MIN Se-Kabupaten Sambas tidak terfokus dalam kinerjanya sebagai guru untuk menyiapkan segala aktivitas yang mendukung untuk siswa di dalam meningkatkan kualitas prestasi belajar siswa.

b. Kurangnya minat guru untuk menambah wawasan sebagai upaya untuk meningkatkan profesionalismenya, oleh karena bertambah atau tidaknya pengetahuan serta kemampuan dalam melaksanakan tugas rutin tidak berpengaruh terhadap pendapatan yang diperolehnya.

c. Jumlah murid dalam satu kelas cukup banyak dan beban guru cukup besar dalam satu minggu.

d. Profesionalismenya belum terbangun dengan baik dan

e. Rendahnya minat guru terhadap dunia tulis menulis, sehingga semua pekerjaan menyulitkan pekerjaan menyulitkan dirinya.

\section{Kesimpulan}

Berdasarkan hasil penelitian yang disimpukan ini akan dikemukakan beberapa implikasi yang dianggap relevan dengan penelitian, implikasi tersebut antara lain sebagai berikut :

Hasil pengolahan dan analisis data menunjukkan bahwa kinerja guru yang bersertifikasi memberikan pengaruh yang signifikan terhadap prestasi belajar siswa sebesar 39,3\%. Pengaruh ini dirasa rendah, hasil temuan penelitian ini diperlukan upaya-upaya untuk meningkatkan kinerja guru yang sudah bersertifikasi dapat dilakukan dengan jalan :

a. Mengirim guru untuk mengikuti pelatihan-pelatihan. Diantaranya pelatihan membuat perangkat program pembelajaran maupun pelatihan dalam 
menggunakan media teknologi.

b. Memberikan kesempatan kepada guru bersertifikasi untuk mengikuti kegiatan pelatihan, penataran, workshop dan seminar pendidikan.

c. Mengikuti MGBS (Musyawarah Guru Bidang Studi) yaitu merupakan musyawarah yang bertujuan untuk menyatukan, mengevaluasi dan mencari solusi atas kekurangan-kekurangannya dalam proses belajar mengajar.

d. Menambah pengetahuan baru dengan menggunakan media cetak atau media masa. Selain berdasarkan buku pegangan, guru juga memanfaatkan adanya media cetak atau media masa sebagai salah satu sumber ilmu pengetahuanya.

e. Hasil pengolahan dan analisis data menunjukkan bahwa pengaruh kinerja guru pada guru belum bersertifikasi memberikan pengaruh yang signifikan terhadap prestasi belajar siswa sebesar $25,7 \%$, nilai ini dikatakan rendah dari kinerja guru bersertifikaso indikasinya bahwa pengaruh kinerja guru belum bersertifikasi harus lebih ditingkatkan lagi.

Hasil temuan penelitian ini diperlukan upaya-upaya untuk meningkatkan kinerja guru supaya prestasi belajar siswa di MIN Se-Kabupaten Sambas meningkat dapat dilakukan dengan jalan:

a. Memberikan insentif dan penghargaan kepada guru yang belum bersertifikasi untuk menambah semangat kerjanya dalam melaksanakan tugasnya.

b. Memberikan kepercayaan dan tanggung jawab kepada guru belum bersertifikasi untuk melaksanakan dan mengelola tugasnya secara mandiri.

c. Memberikan kesempatan kepada guru yang belum bersertifikasi untuk terlibat setiap kegiatan yang mendatangkan manfaat untuk kesejahteraan guru tersebut.

d. Mengadakan evaluasi dan pembinaan secara rutin kepada para guru berkaitan dengan pelaksanaan dengan kinerja guru.

\section{Daftar Pustaka}

AH.Hujair Sanaky, 2005, Sertifikasi Dan Profesionalisme Guru Di Era Reformasi Pendidikan. Jurnal Pendidikan Islam, Jurusan Tarbiyah, 2 (5)

Azwar, Saifuddin. 1999. Metode Penelitian. (Yogyakarta : Pustaka Pelajar).

Baharuddin, Esa Nur Wahyuni, 2012. Teori Belajar dan Pembelajaran, (Jogjakarta: ArRuzz Media).

Gunarsa, Singgih D. Psikologi Perkembangan Anak dan Remaja, Jakarta: Gunung agung, 1991).

Kunandar, Guru Profesional Implementasi Kurikulum KTSP, (Jakarta: PT Rajagrafindo Persada, 2007).

Lili Ng Chui Mi, Meningkatkan Kemampuan Guru Yang Telah Disertifikasi Dalam Menyusun Rencana Pelaksanaan Pembelajaran Melalui Bimbingan Berkelanjutan Pada Sekolah Binaan Di Sambas, Jurnal Visi Ilmu Pendidikan. 
M.A, Muhaimin. Wacana Pengembangan Pendidikan Agama Islam, (Yogyakarta: Pustaka Pelajar, 2003).

Peraturan Pemerintah (PP) no. 19 tahun 2005.

Rizali dkk, Dari Guru Konvensional menuju Guru Profesional, (Jakarta: Kompas Gramedia, 2009).

Rusman, 2011, Model-Model Pembelajaran; Mengembangkan Profesionalisme Guru, (Jakarta: PT RajaGrafindo Persada).

Saondi, Ondi. 2010. Etika Profesi Keguruan, Bandung: PT Rafika Aditama.

Slameto. 2003. Belajar dan Faktor-Faktor yang Mempengarubinya. (Jakarta: Rineka Cipta).

Sudjana,Nana. 1995. Dasar-dasar proses Belajar Mengajar, (Bandung: Sinar Baru Algesindo).

Survei di sini adalah penelitian dengan tidak melakukan perubahan (tidak ada perlakukan khusus) terhadap variabel-variabel yang diteliti. Iqbal Hasan.

Trianton, Teguh. 2008, Sertifikasi Guru Tak Menunjang Mutu Pendidikan, (Online), (www.kabarindonesia.com), di akses 3 Pebruari 2013)

Undang-Undang R.I. Nomor. 14 Tahun 2005, tentang Guru dan Dosen.

Wahyudi, Imam. 2012, Pengembangan Pendidikan, Strategi Inovarif \& Kreatif Dalam Mengelola Pendidikan secara Komprehensif, (Jakarta: PT Prestasi Pustakaraya).

Yamin, Maritis Maisah. 2010, Standarisasi Kinerja Guru, (Jakarta:GP Press).

Yasin, A.Fatah. 2008, Dimensi-dimensi Pendidikan Islam, (Malang:UIN-Malang Press).

Zen, Muhammad. 2010, Kiat Sukses Mengikuti Sertifikasi Guru, (Malang: Cakrawala Media Publisher). 